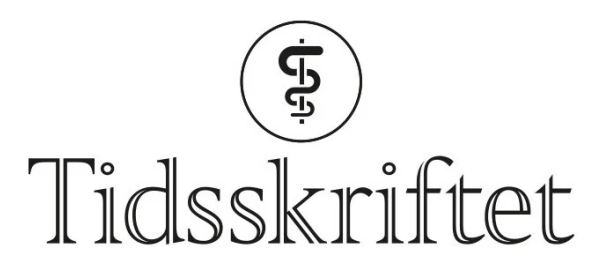

DEN NORSKE LEGEFORENING

\title{
Når evidensen vakler
}

\author{
LEGELIVET
}

\section{ANDREAS NYDAL}

andnyd@gmail.com

Andreas Nydal er lege i spesialisering i psykiatri ved Ruspoliklinikken, Lovisenberg DPS, Lovisenberg Diakonale Sykehus.

\section{Hva vil vi tenke om en lege som vegrer seg for å skrive ut antidepressiver til deprimerte?}

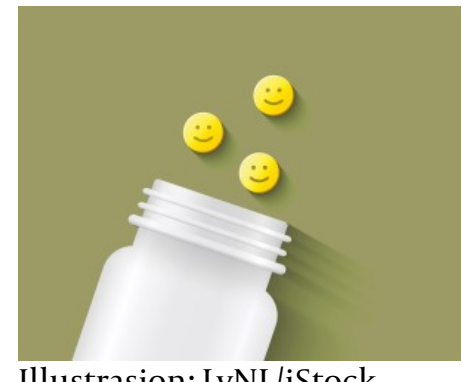

Illustrasjon: LvNL/iStock

Som fersk lege er kunnskapsbasert medisin grunnen jeg står på. Kunnskapsbasert praksis kan illustreres med et venndiagram bestående av tre like store sirkler som representerer henholdsvis evidens, pasientpreferanser og klinisk erfaring (1). I praksis er det nok mer slik at enhver lege har sitt eget venndiagram, hvor størrelsen på sirklene varierer på like mange måter som antallet leger.

Utdanningen vår fasiliterer en forkjærlighet for evidensen, naturligvis, som det eneste kunnskapsbaserte beinet vi har å stå på tidlig i karrieren. Problemet dukker opp når evidensen vakler. Som for eksempel når jeg, som LIS-lege i psykiatri, lurer på hvilket antidepressivum jeg skal velge. Ifølge nasjonal retningslinje er selektive serotoninreopptakshemmere (SSRI) blant medikamentelle førstevalg ved moderat til alvorlig depresjon (므). 179804 nordmenn hentet ut resept på et slikt medikament i 2018, klart flest av alle antidepressiver (3). Samtidig har regionale legemiddelinformasjonssentre (RELIS) gjennomgått effektgrunnlaget og mener gevinsten er minimal sammenlignet med placebo (4.). Også ifølge UpToDate er gevinsten av SSRI-midler liten sammenlignet med placebo, rundt 3 poengs reduksjon på Hamilton Rating Scale for Depression (5).

Den oppsummerte evidensen framstår for meg usikker. Men også framskaffelsen av evidensen er det blitt stilt spørsmålstegn ved (므). U.S. Food and Drug Administration (FDA) mottok 74 studier til registrering mellom 1987 og 2004 som omhandlet antidepressiver. Av disse viste 38 studier at antidepressiver hadde effekt, og 37 av dem ble publisert. Til 
sammenlikning ble kun 3 av de 36 studiene som ikke viste effekt av antidepressiver, direkte publisert. 11 av dem ble publisert på en slik måte at det virket som om antidepressiver hadde effekt. Studiene som ikke ble publisert, er ikke dårlige studier. Det er snakk om forskning med studieprotokoller etter internasjonale retningslinjer og solid industrifinansiering (ㅁ).

«Når legemiddelindustrien forpurrer evidensen, med eller uten intensjon, svekkes tiltroen til psykofarmaka»

Ja, SSRI-midler ser ut til å ha litt bedre effekt enn placebo, men kan jeg stole på den publiserte litteraturen i lys av det ovenstående? Min evidensbaserte tiltro til disse legemidlene vakler. Til og med etter å ha hørt Jordan Petersons foredrag om serotoninnivåene hos alfahannen hos hummere (7.).

Hva vil vi tenke om en lege som vegrer seg for å gjennomføre nasjonalt anbefalt behandling på bakgrunn av annerledes overbevisning? Jeg bestemmer meg for å gå til kolleger, erfarne fjellfolk, med min tvil og mine spørsmål. Ikke formulert som et presist PICO-spørsmål, men stotrende, nølende og springende. Kunnskapspyramiden ville ledd og kastet meg ut $\mathrm{i}$ ingenmannsland, men av et menneske får jeg gode svar. Antidepressiver har en effekt for noen, sier de. Det kan være de som etter ICD-9 hadde en såkalt endogen depresjon. Det kan være de som har egnet CYP2D6 og serotonintransportør (SERT)-profil. Det kan være de med somatisk syndrom, en mer psykomotorisk svekkelse enn rent depressivt tankeinnhold. Det finnes mange som er så deprimerte at de er utilgjengelige for samtaleterapi. Om noen plages med innsovningsvansker eller en komponent av angst i tillegg, har vi enkelte som passer særlig bra. Kommer vi ikke i mål med én, kan vi legge til andre, eller bytte.

Det blir uansett klart at det å sette noen på antidepressiver ikke er gjort i en håndvending. Evidensen, som virker å lide av grov publikasjonsskjevhet, vitner om en liten gevinst sammenlignet med placebo, samtidig som pasientene må velges med farmakokinetisk omhu. Vanskelig, selv uten å ta bivirkninger med i likningen.

Så, hva tenker jeg nå? Er det greit å følge nasjonal retningslinje for behandling, tross manglende tiltro til evidensen? Jeg står i en skvis, most mellom alle sirklene i kunnskapsbasert praksis. Når legemiddelindustrien forpurrer evidensen, med eller uten intensjon (ㅇ) , svekkes tiltroen til psykofarmaka. 90 \% av head-to-head-studier på antipsykotika gikk i studiesponsors favør, som regel uten åpenbar tukling. Dermed er min kliniske psykofarmakologiske hverdag for tiden sterkt påvirket av kollegers kliniske erfaring. Tilliten til psykofarmakas evidens må bygges opp igjen, før den kan konkurrere med de to andre bastionene i kunnskapsbasert praksis. Og imens stoler jeg på erfarne kolleger.

\section{LITTERATUR}

1. Helsebiblioteket. Kunnskapsbasert praksis. httpss://www.helsebiblioteket.no/kunnskapsbasertpraksis Lest 22.1.2020.

2. Nasjonale retningslinjer for diagnostisering og behandling av voksne med depresjon i primær- og spesialisthelsetjenesten. IS-1561. Oslo: Helsedirektoratet, 2009. https://www.helsedirektoratet.no/retningslinjer/voksne-meddepresjon/Voksne\%2omed\%2odepresjon\%20\%E2\%80\%93\%20Nasjonal\%2oretningslinje\%2ofor\%2odiagn ostisering\%20og\%2obehandling\%20\%2oi\%2oprim\%C3\%A6r-

\%20og\%2ospesialisthelsetjenesten.pdf/_/attachment/inline/edod2ef2-da11-4c4e-942358e1b6ddc4d9:961cda6577d48345aaod6feg642b6b6acc2a6506/Voksne\%2omed\%2odepresjon\%20\%E2\%8 0\%93\%20Nasjonal\%2oretningslinje\%2ofor\%2odiagnostisering\%20og\%2obehandling\%20\%20i\%2oprim\% C3\%A6r-\%20og\%2ospesialisthelsetjenesten.pdf

3. Reseptregisteret. http://www.reseptregisteret.no/Prevalens.aspx Søk på alle typer antidepressiva No6AA-No6AX for begge kjønn i 2018. Søk utført 22.1.2020. 
4. RELIS. Hvor effektive er egentlig SSRI mot depresjon? https://relis.no/content/4839/Hvor-effektiveer-egentlig-SSRI-mot-depresjon Lest 22.1.2020.

5. Simon G. Unipolar depression adults: Choosing initial treatment. UpToDate.

https://www.uptodate.com/contents/unipolar-major-depression-in-adults-choosing-initialtreatment\#H21696468 Lest 22.1.2020.

6. Turner EH, Matthews AM, Linardatos E et al. Selective publication of antidepressant trials and its influence on apparent efficacy. N Engl J Med 2008; 358: 252-6o. [PubMed][CrossRef]

7. The Conversation. Psychologist Jordan Peterson says lobsters help to explain why human hierarchies exist - do they? https://theconversation.com/psychologist-jordan-peterson-says-lobstershelp-to-explain-why-human-hierarchies-exist-do-they-90489 Lest 22.1.2020.

8. Montgomery JH, Byerly M, Carmody T et al. An analysis of the effect of funding source in randomized clinical trials of second generation antipsychotics for the treatment of schizophrenia. Control Clin Trials 2004; 25: 598-612. [PubMed][CrossRef]

Publisert: 4. mai 2020. Tidsskr Nor Legeforen. DOI: 10.4045/tidsskr.19.0699

(C) Tidsskrift for Den norske legeforening 2023. Lastet ned fra tidsskriftet.no 26. april 2023. 